\title{
Major Outer Membrane Proteins: Common Antigens in Enterobacteriaceae Species
}

\author{
By H. HOFSTRA* AND J. DANKERT \\ Laboratory for Medical Microbiology, State University Groningen and Division of Hospital \\ Infections, University Hospital A.Z.G., Oostersingel 59, 9713 EZ Groningen, The Netherlands
}

(Received 7 December 1979)

\begin{abstract}
The major outer membrane $(\mathrm{OM})$ proteins of 23 enterobacterial strains (principally clinical isolates) and five non-Enterobacteriaceae species were investigated by the sodium dodecyl sulphate-polyacrylamide gel immunoperoxidase (SGIP) technique to evaluate antigenic cross-reactivity among these proteins. All enterobacterial strains contained one or more peptidoglycan-associated major OM proteins, cross-reactive with the peptidoglycan-bound protein I of Escherichia coli, and one non-peptidoglycan-bound heat-modifiable protein, cross-reactive with protein II* of $E$. coli. Results indicated that antigenic cross-reactivity of the major OM proteins is a general phenomenon in the family Enterobacteriaceae, independent of any molecular weight variation of the corresponding proteins in different bacterial strains. SGIP experiments carried out with OM preparations of other species showed no cross-reactivity of any of their OM proteins with enterobacterial major OM proteins. The significance of the immunological relatedness of OM proteins for the classification of some Enterobacteriaceae is discussed.
\end{abstract}

\section{INTRODUCTION}

The outer membrane (OM) of members of the family Enterobacteriaceae contains two to four major proteins in the 30000 to 42000 molecular weight range (Lugtenberg et al., 1977). In Escherichia coli K12 these proteins have been well characterized. Some, designated Ia and Ib (Schmitges \& Henning, 1976) or b and c (Lugtenberg et al., 1975), are associated with the peptidoglycan layer. Another protein, the heat-modifiable protein II* (Garten et al., 1975) or d (Lugtenberg et al., 1975), is not peptidoglycan-associated and can be solubilized in buffer containing sodium dodecyl sulphate (SDS) at $37^{\circ} \mathrm{C}$ (Reithmeier \& Bragg, 1974). The presence of peptidoglycan-bound and non-peptidoglycan-bound proteins has been detected in the OM of various species of Enterobacteriaceae (Ames et al., 1974; Lugtenberg et al., 1977; Rottem et al., 1979).

The antigenic cross-reactivity of the major OM proteins in Enterobacteriaceae species was previously investigated using the interfacial immunoprecipitation test (Hofstra \& Dankert, 1979). In these experiments, carried out with antiserum prepared against whole formaldehyde-fixed bacteria, a weak though significant cross-reactivity was detected among the major OM proteins of several $E$. coli serotypes, while a weaker cross-reactivity was found with OM proteins of Salmonella typhimurium, Klebsiella pneumoniae and Proteus vulgaris. The antiserum applied in these experiments contained a low titre of antibodies against OM proteins, as shown recently using the enzyme-linked immunosorbent assay (Hofstra \& Dankert, 1980a). Furthermore, the compulsory use of SDS as a solubilizing agent in interfacial immunoprecipitation experiments performed with OM preparations may have reduced the sensitivity of this test.

The SDS-gel immunoperoxidase (SGIP) technique, developed by Van Raamsdonk et al. 
(1977), was used for the immunochemical characterization of Neisseria meningitidis OM (Poolman et al., 1978). Using this method it was possible to demonstrate the antigenic relationship between OM proteins of a wild-type strain of $E$. coli and four species of the genus Proteus (Hofstra \& Dankert, 1980 b), although CNBr cleavage experiments failed to demonstrate any similarities between the peptidoglycan-bound major OM proteins of $E$. coli K12 and P. mirabilis (Datta et al., 1976).

In this study we have used the SGIP technique to investigate the antigenic relationship of the major OM proteins in seven serotypes of $E$. coli, sixteen related Enterobacteriaceae species and five Gram-negative rod-like bacteria not belonging to the Enterobacteriaceae.

\section{METHODS}

Bacterial strains and growth conditions. Escherichia coli, serotypes $01 \mathrm{~K}^{-}, 026 \mathrm{~K} 60,055 \mathrm{~K} 59$ and $075 \mathrm{~K}^{-}$, Edwardsiella tarda, Salmonella typhimurium VI 260, Citrobacter freundii, Klebsiella pneumoniae (K. aerogenes), Enterobacter aerogenes, Ent . cloacae, Serratia marcescens, Proteus vulgaris, P. morganii (Morganella morganii), P. rettgeri, P. mirabilis, Providencia stuartii (Proteus stuartii), Pseudomonas aeruginosa, Aeromonas hydrophila, Acinetobacter calcoaceticus subtype anitratus and Alcaligenes faecalis were isolated from faecal samples obtained from healthy subjects. Escherichia coli $\mathrm{O} 4 \mathrm{~K} 2$ was isolated from an infected wound in the oral cavity of a seal. Shigella flexneri, Salmonella panama, S. braenderup and $S$. derby were isolated from faecal samples obtained from patients with diarrhoea. Pseudomonas fluorescens was isolated from a contaminated sink. Escherichia coli $0111 \mathrm{~K} 58$ and its galactose epimerase-deficient mutant strain J5 were supplied by Dr B. Witholt, Laboratory of Biochemistry, State University, Groningen. Strains of E. coli and Salmonella were serotyped by the Rijksinstituut voor de Volksgezondheid, Bilthoven, The Netherlands. The other strains were identified in our laboratory according to Cowan (1975) and Lennette et al. (1978). Nomenclature according to the Manual of Clinical Microbiology (Lennette et al., 1978) was used in this study. Alternative names for some strains, as preferred by Cowan (1975), are given in parentheses. Bacteria were grown as previously described (Hofstra \& Dankert, 1979).

Isolation of outer membrane. Outer membranes (OM) of E. coli strains were isolated by Triton X-100 extraction of a crude envelope fraction according to Schnaitman (1971) as described in detail for $E$. coli O26K60 (Dankert \& Hofstra, 1978). From the other bacterial species, OM were isolated by a simple and quick method developed by P. Sloots and B. Witholt, Laboratory of Biochemistry, State University, Groningen (unpublished procedure). Briefly, late-exponential phase cells from a 31 culture were washed with

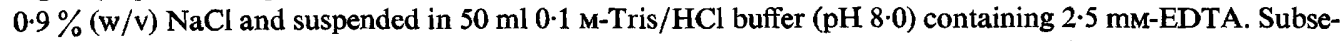
quently, cells were subjected to a series of short sonic oscillations ( 20 to $30 \mathrm{~s}$; MSE, London), each period being followed by cooling on ice. Sonic treatment was continued until the absorbance of the suspension, measured at $450 \mathrm{~nm}$ (Beckman, Fullerton, Calif., U.S.A.), had decreased to approximately $10 \%$ of the original value. Unbroken cells were removed by centrifugation $\left(6000 \mathrm{~g}, 10 \mathrm{~min}, 4^{\circ} \mathrm{C}\right)$. The supernatant was then centrifuged at $30000 \mathrm{~g}$ for $20 \mathrm{~min}$ at $4^{\circ} \mathrm{C}$. The sediment was washed twice with deionized water and lyophilized (Edwards, Crawley, Sussex). The resulting preparation was almost pure OM as analysed by polyacrylamide gel electrophoresis. Subsequent Triton X-100 extraction of these fractions according to Schnaitman (1971), to remove contaminating cytoplasmic membrane material, did not significantly change the electrophoretic profile of the major OM protein range ( 25000 to 42000 molecular weight). This extraction step was therefore usually omitted.

Extraction of non-peptidoglycan-bound OM proieins. OM were dispersed to a concentration of $1 \mathrm{mg} \mathrm{ml}^{-1}$ in $62.5 \mathrm{mM}$-Tris/ $\mathrm{HCl}$ buffer (pH 6.7) containing $2 \%$ (w/v) SDS, followed by incubation at $37^{\circ} \mathrm{C}$ for $30 \mathrm{~min}$. The insoluble material was sedimented by centrifugation at $110000 \mathrm{~g}$ for $30 \mathrm{~min}$ at $15^{\circ} \mathrm{C}$. To investigate possible heat-modifiability of the extracted proteins the supernatants were divided in two equal parts, one of which was heated at $100^{\circ} \mathrm{C}$ for $10 \mathrm{~min}$, and the other kept at room temperature. Subsequently both samples were supplemented with glycerol $(10 \%, \mathrm{v} / \mathrm{v})$ and Bromophenol Blue $(0.001 \%, \mathrm{w} / \mathrm{v})$ and analysed by polyacrylamide gel electrophoresis.

Isolation of OM proteins of E. coli O26K60. Major OM proteins I and II* and murein-lipoprotein were isolated and purified as described previously (Hofstra \& Dankert, 1980a).

Isolation of lipopolysaccharide (LPS). LPS of E. coli O26K60 was isolated according to Westphal et al. (1952) as described previously (Hofstra \& Dankert, 1979).

Preparation of antisera. Antisera against the isolated OM proteins I and II* of $E$. coli $\mathrm{O} 26 \mathrm{~K} 60$ were elicited by intramuscular administration to rabbits. Two pairs of rabbits received $5 \mathrm{mg}$ protein I or II*, respectively, suspended in $0.5 \mathrm{ml} 0.9 \%(\mathrm{w} / \mathrm{v}) \mathrm{NaCl}$ and the same volume of Freund's complete adjuvant. The antigens 
were administered in the upper hindleg region at days 0 and 28 . Blood was collected 3 weeks after the second injection. Sera were obtained after centrifugation of the clotted blood and stored at $-70^{\circ} \mathrm{C}$. Both types of antiserum contained antibodies against LPS O26. In addition, a considerable amount of anti-murein-lipoprotein was present in the antiserum against protein I. Antisera monospecifically directed against protein I or II* were prepared by absorption of the sera with LPS O26 and murein-lipoprotein (Hofstra \& Dankert, $1980 a$ ). The monospecificity of the absorbed antisera was controlled using the enzyme-linked immunosorbent assay.

Enzyme-linked immunosorbent assay. This was carried out as described by Hofstra \& Dankert (1980a).

$S D S$-polyacrylamide gel electrophoresis (SDS-PAGE). This was carried out according to Laemmli (1970) on slab gels as described by Ames (1974). Staining, destaining and photography of the gels, as well as the application of standard proteins for molecular weight estimation, were described by Dankert \& Hofstra (1978).

SDS-gel immunoperoxidase technique (SGIP). This was performed essentially according to Van Raamsdonk et al. (1977) and Poolman et al. (1978). Briefly, OM preparations of all strains studied were subjected to SDS-PAGE. The unstained gel was cut into $3 \times 4 \mathrm{~cm}$ pieces, each containing three electrophoretic profiles approximately covering the 20000 to 50000 molecular weight range. These gel segments were sliced into $40 \mu \mathrm{m}$ thick sections (American Optical Cryocut, Buffalo, U.S.A.) at $-30^{\circ} \mathrm{C}$, and the sections were incubated for $2 \mathrm{~h}$ at $37^{\circ} \mathrm{C}$ in $1 \mathrm{ml}$ specific antiserum diluted $1: 20$ with phosphate-buffered saline (PBS). Sections were washed with fresh PBS, spread on microscope slides, covered with goat anti-rabbit-IgG conjugated with horseradish peroxidase (Nordic, Tilburg, The Netherlands) and incubated for $1 \mathrm{~h}$ at room temperature. After washing with PBS, sections were covered with peroxidase substrate, composed of $10 \mathrm{ml}$ deionized water, $41 \mathrm{mg}$ sodium acetate, $4 \mathrm{mg} \mathrm{3-amino-9-ethylcarbazole} \mathrm{(Sigma),} 0.5 \mathrm{ml} \mathrm{N}, N$-diethylformamide and $10 \mu \mathrm{l}$ $30 \%(\mathrm{v} / \mathrm{v}) \mathrm{H}_{2} \mathrm{O}_{2}$ (pH 5.0). Those areas of the gel sections where rabbit antibodies had reacted with gel-fixed antigens during the first incubation of the SGIP procedure turned bright red after 5 to 10 min at room temperature. Finally, sections were rinsed with deionized water and dried on microscope slides. SGIP experiments were carried out using antisera against proteins I and II* of $E$. coli $\mathrm{O} 26 \mathrm{~K} 60$ which had been absorbed with LPS and murein-lipoprotein. Preimmunization sera were applied as controls. Sections were photographed as described for SDS-PAGE slab gels.

\section{RESULTS}

\section{Outer membrane protein profiles of several Gram negative bacteria}

Polyacrylamide gel electrophoresis (PAGE) profiles of the major outer membrane (OM) proteins in the 25000 to 45000 molecular weight range of the bacteria studied are shown in Fig. 1. All members of the Enterobacteriaceae showed at least two major OM protein bands (tracks 1 to 23). The regularity of the patterns in the 33000 to 41000 molecular weight range found within the Enterobacteriaceae (except Serratia marcescens, track 18) was not observed in the OM profiles of the other Gram-negative bacteria studied (tracks 24 to 28). No major protein bands were detected in the OM of our strain of Aeromonas hydrophila (track 26). Profiles of E. coli strains, Salmonella typhimurium, Klebsiella pneumoniae, Proteus vulgaris and Pseudomonas aeruginosa were discussed previously (Hofstra \& Dankert, 1979). Our estimates of molecular weight are generally in agreement with those reported by others, though small differences exist for some bacteria. According to our calculations, the molecular weights of the major OM proteins in S. typhimurium are higher than those reported by Ames et al. (1974) but lower than the values reported by Lugtenberg et al. (1977). In $P$. mirabilis our estimates are slightly higher than those given by Rottem et al. (1979).

\section{Non-peptidoglycan-bound outer membrane proteins}

The presence of non-peptidoglycan-bound proteins in the OM preparations was investigated by extracting the OM with $2 \%(\mathrm{w} / \mathrm{v}) \mathrm{SDS}$ at $37^{\circ} \mathrm{C}$. Possible heat-modifiability of the extracted proteins was studied by heating half of the extract at $100{ }^{\circ} \mathrm{C}$ for $10 \mathrm{~min}$, followed by PAGE analysis of both the unheated and the heated samples (Table 1, first column of results). All enterobacterial strains tested contained one non-peptidoglycan-bound major OM protein which showed an apparent molecular weight shift after heating at $100{ }^{\circ} \mathrm{C}$. In all $E$. coli serotypes tested, except $\mathrm{O} 1 \mathrm{~K}^{-}$, this protein, designated protein $\mathrm{II}^{*}$ (Garten et al., 1975), B (Reithmeier \& Bragg, 1974) or d (Lugtenberg et al., 1975), had an apparent molecular weight of 27000 after solubilization at $37^{\circ} \mathrm{C}$, which shifted to 33000 after heating at 


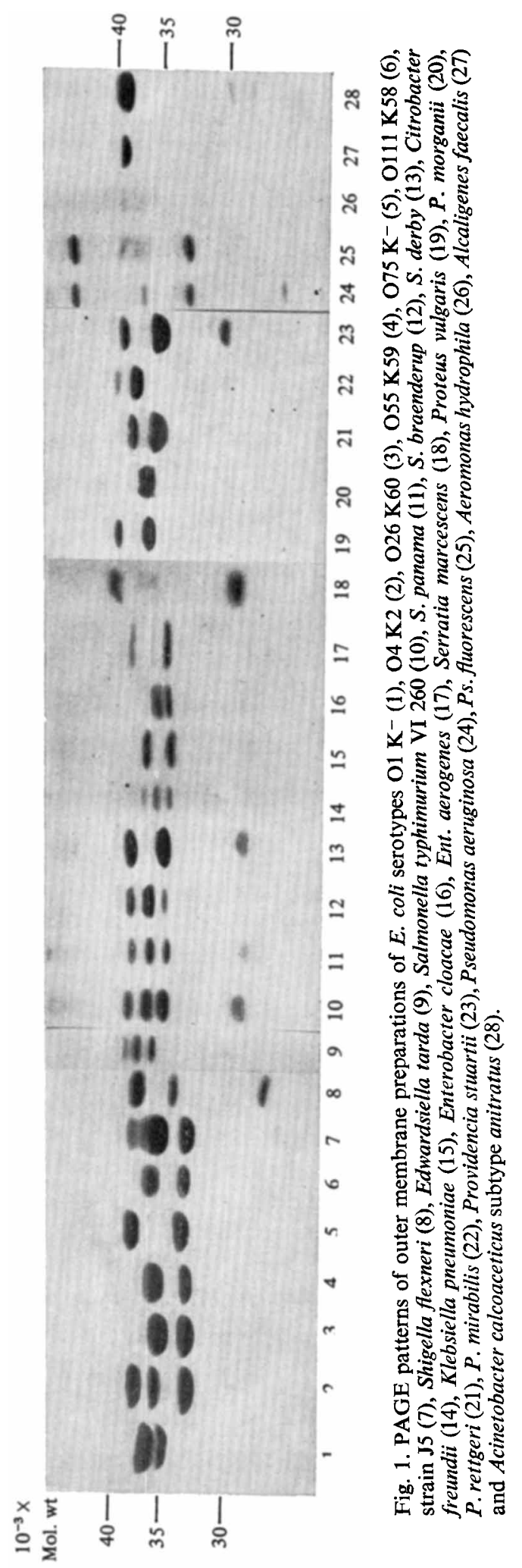


Table 1. Outer membrane proteins of Gram-negative bacteria, their association with the peptidoglycan layer and their antigenic cross-reactivity with the major outer membrane proteins of Escherichia coli $\mathrm{O} 26 \mathrm{~K} 60$

Outer membrane (OM) fractions, prepared as described in Methods, were extracted with buffer containing SDS $\left(30 \mathrm{~min}, 37^{\circ} \mathrm{C}\right)$ to solubilize the non-peptidoglycan-bound proteins. Peptidoglycan and peptidoglycan-bound proteins were removed by centrifugation $\left(110000 \mathrm{~g}, 30 \mathrm{~min}, 15^{\circ} \mathrm{C}\right)$. Heatmodifiability of the extracted proteins was investigated by heating one half of the supernatant $\left(10 \mathrm{~min}, 100^{\circ} \mathrm{C}\right)$, while the other half was kept at room temperature. Both samples were analysed by PAGE (first column of results). Polyacrylamide sections ( $40 \mu \mathrm{m}$ thick) containing PAGE profiles of OM preparations were subjected to the SGIP technique. Proteins cross-reacting with protein I of $E$. coli $\mathrm{O} 26 \mathrm{~K} 60$ are given in the second column of results and proteins cross-reacting with protein $\mathrm{II}^{*}$ of this serotype in the third column. Minor proteins are given in parentheses.

$10^{-3} \times$ Molecular weight

\begin{tabular}{|c|c|c|c|c|c|}
\hline \multirow[b]{2}{*}{ Strain } & \multicolumn{2}{|c|}{$\begin{array}{l}\text { Non-peptidoglycan- } \\
\text { associated OM proteins }\end{array}$} & \multirow{2}{*}{\multicolumn{2}{|c|}{$\begin{array}{l}\text { Peptidoglycan- } \\
\text { associated } \\
\text { OM proteins cross- } \\
\text { reactive with protein } \\
\text { I of } E \text {. coli } \mathrm{O} 26 \mathrm{~K} 60\end{array}$}} & \multirow[t]{2}{*}{$\begin{array}{l}\text { Non-peptidoglycan- } \\
\text { associated } \\
\text { OM proteins } \\
\text { cross-reactive } \\
\text { with protein } \\
\text { II }^{*} \text { of } E \text {. coli } \\
\text { O26 K60 }\end{array}$} \\
\hline & $37^{\circ} \mathrm{C}$ & $100^{\circ} \mathrm{C}$ & & & \\
\hline Escherichia coli $\mathrm{O} 1 \mathrm{~K}^{-}$ & 28 & 35 & 37 & & 35 \\
\hline E. coli $\mathrm{O} 4 \mathrm{~K} 2$ & 27 & 33 & $36 \cdot 5$ & 38 & 33 \\
\hline E. coli $\mathrm{O} 26 \mathrm{~K} 60$ & 27 & 33 & 36 & $(37)$ & 33 \\
\hline E. coli O55 K59 & 27 & 33 & $36 \cdot 5$ & & 33 \\
\hline E. coli $\mathrm{O} 75 \mathrm{~K}^{-}$ & 27 & $33 \cdot 5$ & $(36 \cdot 5)$ & 38 & $33 \cdot 5$ \\
\hline$E$, coli $\mathrm{O} 111 \mathrm{~K} 58$ & 27 & 33 & $36 \cdot 5$ & & 33 \\
\hline E. coli J5 & 27 & 33 & 36 & $37 \cdot 5$ & 33 \\
\hline Shigella flexneri & $26 \cdot 5$ & 34 & 37 & & 34 \\
\hline Edwardsiella tarda & 27 & 36 & 37 & 38 & 36 \\
\hline Salmonella typhimurium & 28 & 35 & $36 \cdot 5$ & 38 & 35 \\
\hline S. panama & 28 & 35 & 36 & 38 & 35 \\
\hline S. braenderup & 28 & 35 & 36 & 38 & 35 \\
\hline S. derby & 28 & $34 \cdot 5$ & 35 & 38 & $34 \cdot 5$ \\
\hline Citrobacter freundii & 28 & 34 & 35 & 36 & 34 \\
\hline Klebsiella pneumoniae & 28 & 34 & $36 \cdot 5$ & & 34 \\
\hline Enterobacter cloacae & 28 & 34 & 35 & & 34 \\
\hline Ent. aerogenes & 28 & 34 & 38 & & 34 \\
\hline Serratia marcescens & 28 & $28(34 \cdot 5)(36)$ & $40 \cdot 5$ & & $28(34 \cdot 5)(36)$ \\
\hline Proteus vulgaris & 29 & 40 & 37 & & 40 \\
\hline P. morganii & 29 & 37 & $37 \cdot 5$ & & 37 \\
\hline$P$. rettgeri & $29 \cdot 5$ & $38 \cdot 5$ & 36 & & $38 \cdot 5$ \\
\hline P. mirabilis & $30 \cdot 5$ & 40 & 38 & & 40 \\
\hline Providencia stuartii & 31 & 39 & $35 \cdot 5$ & & 39 \\
\hline Pseudomonas aeruginosa & 33 & 33 & None & & None \\
\hline Ps. fluorescens & 33 & 33 & None & & None \\
\hline Aeromonas hydrophila & None & None & None & & None \\
\hline Alcaligenes faecalis & None & None & None & & None \\
\hline Acinetobacter calcoaceticus & $(29)$ & $(29)$ & None & & None \\
\hline
\end{tabular}

$100{ }^{\circ} \mathrm{C}$. In $E$. coli $\mathrm{O} 1 \mathrm{~K}^{-}$both the unmodified and the heat-modified form of this protein showed a higher molecular weight than in the other $E$. coli serotypes. The apparent molecular weights of the unmodified forms of the corresponding proteins in the other Enterobacteriaceae ranged from 26500 in Shigella flexneri to 31000 in Providencia stuartii. Somewhat greater differences were found with the heat-modified forms, the estimations ranging from 34000 in several species to 40000 in $P$. vulgaris and $P$. mirabilis. From the OM preparations of $P$. vulgaris and Ent. aerogenes considerable amounts of their non-heat-modifiable proteins were also extracted at $37^{\circ} \mathrm{C}$. Lugtenberg et al. (1977) described this phenomenon for $P$. vulgaris. These proteins are probably more loosely bound to the peptidoglycan layer in these strains than the corresponding proteins of the other bacteria tested. The non-peptido- 


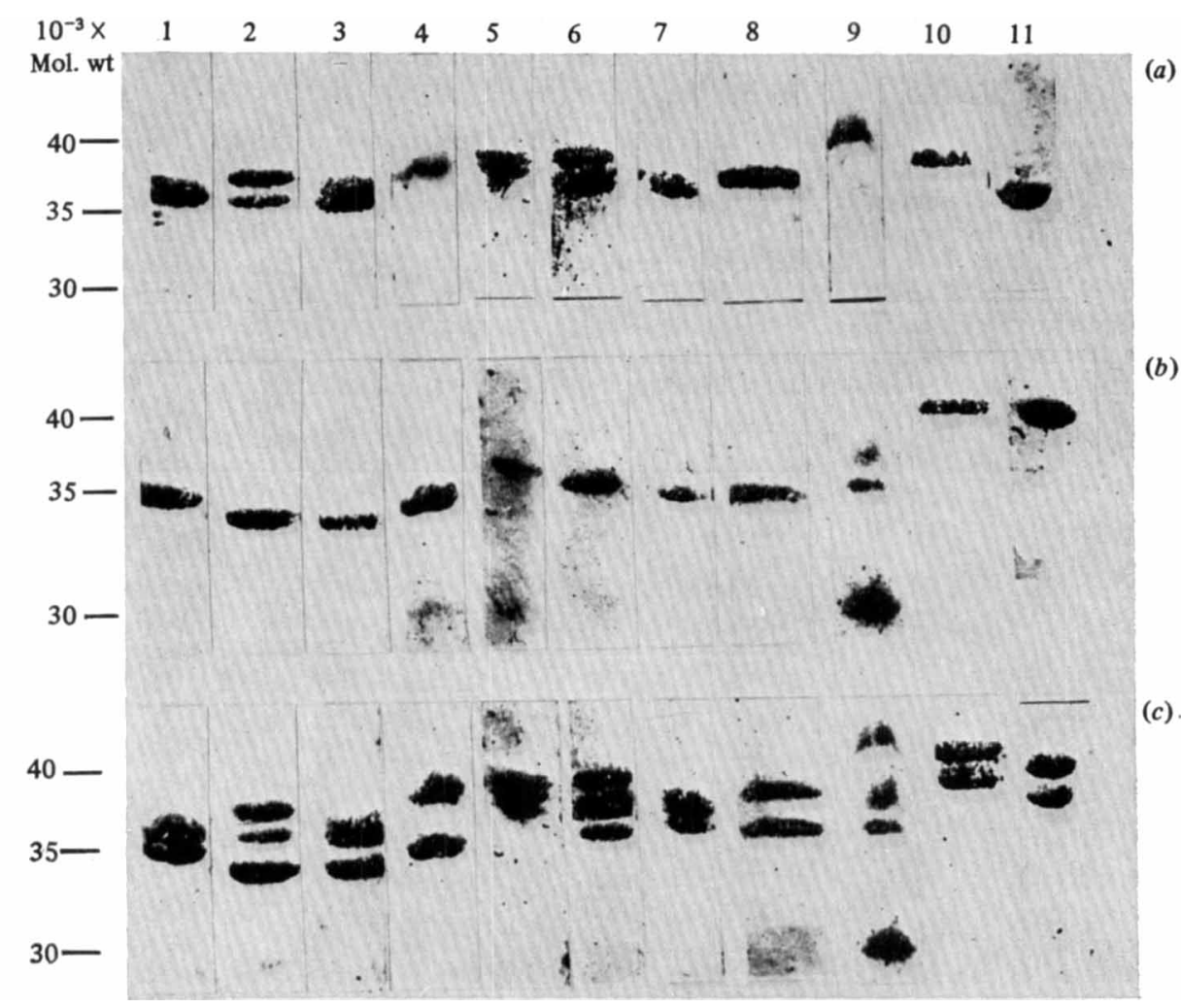

Fig. 2. SGIP profiles of outer membrane preparations of several Enterobacteriaceae species. Polyacrylamide sections ( $40 \mu \mathrm{m}$ thick) contained electrophoretic OM profiles of $E$. coli $\mathrm{O}^{-} \mathrm{K}^{-}$(1), E. coli $\mathrm{O} 4 \mathrm{~K} 2$ (2), E. coli O26 K60 (3), Shigella flexneri (4), Edwardsiella tarda (5), Salmonella typhimurium (6), Citrobacter freundii (7), Klebsiella pneumoniae (8), Serratia marcescens (9), Proteus mirabilis (10) and Providencia stuartii (11). Sections were treated with antiserum against $O M$ protein I of $E$. coli $\mathrm{O} 26 \mathrm{~K} 60(a)$, antiserum against OM protein $\mathrm{II}^{*}$ of the same serotype (b) or a combination of both these antisera $(c)$.

glycan-bound protein of $S$. marcescens showed an unexpected property concerning its heatmodifiability. Most of this protein was found in the unmodified form (molecular weight 28000 ) even after boiling in $2 \%(\mathrm{w} / \mathrm{v})$ SDS for $30 \mathrm{~min}$. Furthermore, the heat-modified form gave two weak bands with apparent molecular weights of 34500 and 36000 , respectively. Consequently, three bands were found after boiling the protein extracted from $S$. marcescens $\mathrm{OM}$ at $37^{\circ} \mathrm{C}$. From the $\mathrm{OM}$ preparations of the species not belonging to the Enterobacteriaceae, few proteins were extracted with SDS at $37^{\circ} \mathrm{C}$. None of the extracted proteins showed a change in apparent molecular weight after heating to $100^{\circ} \mathrm{C}$.

\section{Antigenic cross-reactivity of outer membrane proteins}

The results of SGIP experiments performed with polyacrylamide sections containing PAGE profiles of OM preparations from a representative selection of bacteria are shown in Fig. 2. The application of the antiserum specifically directed against protein I of $E$. coli O26 K60 resulted in SGIP profiles showing one or two major OM protein bands (Fig. $2 a$ ). In the profiles of E. coli serotypes, Sh. flexneri, Edwardsiella tarda, S. typhimurium, Citrobacter freundii, $K$. pneumoniae and Ser. marcescens the higher molecular weight bands were stained (tracks 1 to 9) while in P. mirabilis and Prov. stuartii the lower molecular weight bands had reacted with anti-protein I (tracks 10 and 11). When antiserum against protein II* of $E$. coli $\mathrm{O} 26 \mathrm{~K} 60$ was used, SGIP profiles showed a positive reaction of the higher 
molecular weight bands in P. mirabilis and Prov. stuartii (Fig. $2 b$, tracks 10 and 11), while in all other profiles the lower molecular weight bands were stained. In the Ser. marcescens OM profile (track 9) three bands reacted with anti-protein $\mathrm{II}^{*}$ : the unmodified non-peptidoglycan-bound protein with an apparent molecular weight of 28000 and the two bands (molecular weights 34500 and 36000 ) possibly representing heat-modified forms of this protein. When a combination of antisera against OM proteins I and II* of E. coli $\mathrm{O} 26 \mathrm{~K} 60$ was used, SGIP profiles obtained showed a complete set of major OM proteins (Fig. $2 c$ ), similar to the Coomassie Brilliant Blue-stained OM protein patterns shown in Fig. 1. Results obtained in SGIP experiments carried out with OM preparations of all bacteria studied are given in Table 1 (second and third columns). In all Enterobacteriaceae studied, the peptidoglycan-bound major OM proteins reacted with antiserum against protein I of E. coli $\mathrm{O} 26 \mathrm{~K} 60$, while the non-peptidoglycan-bound, heat-modifiable proteins were cross-reactive with protein II* of E. coli O26 K60. In Proteus species (except P. morganii) and in Prov. stuartii the higher molecular weight protein was non-peptidoglycan-bound and cross-reactive with protein II*, while the lower band reacted with anti-protein I.

SGIP experiments carried out with OM preparations of bacteria not belonging to the Enterobacteriaceae showed no cross-reactivity of any of their OM proteins with proteins I or II* of E. coli $\mathrm{O} 26 \mathrm{~K} 60$.

Preimmunization sera applied to SGIP sections as controls were always negative.

\section{DISCUSSION}

The major OM proteins of the 23 enterobacterial strains studied showed a high degree of regularity in their PAGE profiles and in their antigenic cross-reactivity with the major $\mathrm{OM}$ proteins of $E$. coli $\mathrm{O} 26 \mathrm{~K} 60$. All strains tested contained one or more peptidoglycanbound OM proteins and one non-peptidoglycan-bound, heat-modifiable major OM protein.

The presence of heat-modifiable, non-peptidoglycan-bound OM proteins in Enterobacteriaceae other than $E$. coli has been reported by several authors. Ames et al. (1974) and Nurminen (1978) described the heat-modifiability of the lower molecular weight major OM protein in S. typhimurium. Lugtenberg et al. (1977) reported that the lower molecular weight OM protein of $C$. freundii, Ent. cloacae, $K$. aerogenes, $S$. typhimurium and Ser. marcescens was not bound to the peptidoglycan layer, while in $P$. vulgaris and $P$. mirabilis the higher molecular weight major OM protein was not peptidoglycan-bound. This is in agreement with our findings. Rottem et al. (1979) described the heat-modifiability of the non-peptidoglycan-bound OM protein in $P$. mirabilis.

Results of SGIP experiments indicate that antigenic cross-reactivity of the major OM proteins is a general phenomenon in the Enterobacteriaceae independent of variation in the molecular weight of the corresponding proteins in different bacterial strains. However, the cross-reactivity of the peptidoglycan-associated proteins should probably be treated with some reserve. Proteolytic cleavage experiments (Lee et al., 1979) gave strong evidence that OM proteins $1 \mathrm{a}$ and $1 \mathrm{~b}$ of $E$. coli $\mathrm{K} 12$ (b and c according to Lugtenberg et al., 1975) are clearly different, which is in agreement with results obtained by Ichihara \& Mizushima (1978). Their results indicate that antigenic identity of these porin proteins of $E$. coli K12 is unlikely, although the presence of shared antigenic determinants is not excluded by their experiments. In our SGIP experiments all peptidoglycan-bound major OM proteins of all Enterobacteriaceae species studied reacted with the antiserum elicited against the peptidoglycan-bound protein I of wild-type $E$. coli $\mathrm{O} 26 \mathrm{~K} 60$. This was also the case in those strains possessing more than one peptidoglycan-bound major $\mathrm{OM}$ protein, e.g. E. coli $\mathrm{O} 4 \mathrm{~K} 2$, Edwardsiella tarda, Salmonella serotypes and C. freundii, which indicates that in these strains all peptidoglycan-bound proteins are antigenically related to protein I of E. coli O26 K60. However, it should be noted that protein I of E. coli $\mathrm{O} 26 \mathrm{~K} 60$ is not composed of a single polypeptide. About $90 \%$ of it is represented by the protein of 36000 molecular weight and 
approximately $10 \%$ consists of a polypeptide of 37000 molecular weight (not visible in Fig. 1). Possibly, antibodies against the minor 37000 molecular weight component were also present in our antiserum against protein I. Therefore we cannot completely exclude the possibility that some of the peptidoglycan-bound OM proteins of heterologous enterobacterial strains cross-reacted with the minor 37000 molecular weight protein of $E$. coli O26 K60 rather than with its major 36000 molecular weight protein. The SGIP method would be very useful for investigating the antigenic relationship of the numerous major and minor OM proteins of $E$. coli $\mathrm{K} 12$ described so far.

A comparison of the results obtained by the SGIP technique with those of interfacial immunoprecipitation experiments (Hofstra \& Dankert, 1979, 1980a) shows that the former method is both more specific and much more sensitive than the latter. However, the SGIP technique is not a quantitative assay. It discriminates strictly between antigenically related and unrelated proteins. Furthermore, this procedure implies a previous separation of the proteins on polyacrylamide gels after boiling the OM samples in SDS-containing buffer. Therefore results obtained with the SGIP method do not indicate the actual immunological relationship of the OM proteins in their native configuration, i.e. as organized within the OM structure and more or less covered by lipopolysaccharide or capsular materials. In immunofluorescence experiments, antibodies against protein II* of E. coli O26 K60 were shown to adhere to intact cells of the homologous strain (Hofstra et al., 1979). Results obtained in these experiments with an antiserum against a denatured preparation of protein I, as used in the SGIP technique, were disappointing. Antibodies elicited against the denatured form of protein I hardly reacted with this protein in its native configuration, in contrast to antibodies prepared against the undenatured protein $(H$. Hofstra \& J. Dankert, unpublished results).

The classification of the Enterobacteriaceae largely rests on biochemical characteristics (Clancy, 1974; Cowan, 1975; Ewing \& Martin, 1978) and on the relationships of bacterial DNAs (Brenner \& Falkow, 1971). It is tempting to draw parallels between this classification and the immunological relatedness of the major OM proteins within the subgroups (tribes) of the family Enterobacteriaceae. In general, the properties of the OM proteins (the similarity of PAGE profiles and the antigenic cross-reactivity) are in agreement with the accepted classification. However, in the case of the tribe Proteeae, which contains four Proteus species and two species of the genus Providencia according to Ewing \& Martin (1978), our observations would favour the classification according to Cowan (1975), who preferred the nomenclature Proteus stuartii instead of Providencia stuartii and who distinguished Morgan's bacillus number 1 (Morgan, 1906) as a separate genus (Morganella) rather than as a Proteus species ( $P$. morganii).

\section{REFERENCES}

AMEs, G. F. (1974). Resolution of bacterial proteins by polyacrylamide gel electrophoresis on slabs. Membrane, soluble, and periplasmic fractions. Journal of Biological Chemistry 249, 634-644.

Ames, G. F., Spudich, E. N. \& Nikaido, H. (1974). Protein composition of the outer membrane of Salmonella typhimurium: effect of lipopolysaccharide mutations. Journal of Bacteriology 117, 406-416.

BrenNer, D. J. \& Falkow, S. (1971). Molecular relationships among members of the family Enterobacteriaceae. Advances in Genetics 16, 81-118.

Clancy, C. F. (1974). Enterobacteriaceae. In CRC Handbook of Microbiology, vol. I, Organismic Microbiology, pp. 230-238. Edited by A. I. Laskin \& H. A. Lechevalier. Cleveland: CRC Press.

Cowan, S. T. (1975). Cowan and Steel's Manual for the Identification of Medical Bacteria, 2nd edn. Cambridge: Cambridge University Press.

Dankert, J. \& Hofstra, H. (1978). Antibodies against outer membrane proteins in rabbit antisera prepared against Escherichia coli O26K60. Journal of General Microbiology 104, 311-320.

DATTA, D. B., Krämer, C. \& Henning, U. (1976). Diploidy for a structural gene specifying a major protein of the outer cell envelope membrane from Escherichia coli $\mathrm{K}-12$. Journal of Bacteriology 128, 834-841.

Ewing, W. H. \& Martin, W. J. (1978). Enterobacteriaceae. In Manual of Clinical Microbiology, 2nd edn., pp. 189-221. Edited by E. H. Lennette, E. H. Spaulding \& J.P. Truant. Washington, D.C.: American Society for Microbiology.

Garten, W., Hindennach, I. \& Henning, U. (1975). The major proteins of the Escherichia coli outer 
cell envelope membrane. Characterization of proteins II* and III, comparison of all proteins. European Journal of Biochemistry 59, 215-221.

Hofstra, H. \& Dankert, J. (1979). Antigenic crossreactivity of major outer membrane proteins in Enterobacteriaceae species. Journal of General Microbiology 111, 293-302.

Hofstra, H. \& DANkerT, J. (1980a). Preparation and quantitative determination of antibodies against major outer membrane proteins of Escherichia coli O26 K60. Journal of General Microbiology 117, $437-447$.

Hofstra, H. \& Dankert, J. (1980 b). Antigenic cross-reactivity of outer membrane proteins of $E$. coli and Proteus species. FEMS Microbiology Letters 7 (in the Press).

Hofstra, H., Van Tol, M. J. D. \& Dankert, J. (1979). Immunofluorescent detection of the major outer membrane protein II* in Escherichia coli $^{*}$ O26K60. FEMS Microbiology Letters 6, 147-150.

ICHIHARA, S. \& MizuShima, S. (1978). Characterization of major outer membrane proteins $\mathrm{O}-8$ and 0-9 of Escherichia coli K-12. Evidence that structural genes for the two proteins are different. Journal of Biochemistry 83, 1095-1100.

LAEMMLI, U. K. (1970). Cleavage of structural proteins during the assembly of the head of bacteriophage T4. Nature, London 227, 680-685.

Lee, D. R., Schnaitman, C. A. \& Pugsley, A. P. (1979). Chemical heterogeneity of major outer membrane pore proteins of Escherichia coli. Journal of Bacteriology 138, 861-870.

LennetTe, E. H., Spaulding, E. H. \& Truant, J. P. (editors) (1978). Manual of Clinical Microbiology, 2nd edn. Washington, D.C.: American Society for Microbiology.

Lugtenberg, B , Meyers, J., Peters, R., VAN der Hoek, P. \& Van AlPhen, L. (1975). Electrophoretic resolution of the "Major outer membrane protein' of Escherichia coli K12 into four bands. FEBS Letters 58, 254-258.

Lugtenberg, B., Bronstein, H., van Selm, N. \&
Peters, R. (1977). Peptidoglycan-associated outer membrane proteins in Gram negative bacteria. Biochimica et biophysica acta 465, 571-578.

MORGAN, H. DE R. (1906). Upon the bacteriology of the summer diarrhoea of infants. British Medical Journal i, 908-912.

Nurminen, M. (1978). A mild procedure to isolate the $34 \mathrm{~K}, 35 \mathrm{~K}$ and $36 \mathrm{~K}$ porins of the outer membrane of Salmonella typhimurium. FEMS Microbiology Letters 3, 331-334.

Poolman, J. T., Hopman, C. Th. P. \& Zanen, H. C. (1978). Immunochemical characterization of outer membrane complexes from Neisseria meningitidis by the SDS-polyacrylamide-gel-electrophoresisimmunoperoxidase technique (SGIP). FEMS Microbiology Letters 4, 245-248.

Reithmeier, R. A. F. \& BRAGG, P. D. (1974). Purification and characterization of a heatmodifiable protein from the outer membrane of Escherichia coli. FEBS Letters 41, 195-198.

Rottem, S., Markovitz, O., Hasin, M. \& Razin, S. (1979). Outer membrane proteins of smooth and rough strains of Proteus mirabilis. European Journal of Biochemistry 97, 141-146.

SCHMitges, C. J. \& HenNING, U. (1976). The major proteins of the Escherichia coli outer cell-envelope membrane. Heterogeneity of protein I. European Journal of Biochemistry 63, 47-52.

SCHNAITMAN, C. A. (1971). Solubilization of the cytoplasmic membrane of Escherichia coli by Triton X-100. Journal of Bacteriology 108, 545552.

Van RaAmsdonk, W., Pool, C. W. \& Heyting, C. (1977). Detection of antigens and antibodies by an immunoperoxidase method applied on thin longitudinal sections of SDS-polyacrylamide gels. Journal of Immunological Methods 17, 337-348.

WeSTPHAL, O., LüdeRITZ, O. \& BISTER, F. (1952). Über die Extraktion von Bakterien mit PhenolWasser. Zeitschrift für Naturforschung 7b, 148155. 